\title{
Gibberellic Acid Inhibits Flowering and Reduces Hand Thinning of 'Redhaven' Peach
}

\author{
Elina Coneva ${ }^{1}$ and John A. Cline ${ }^{2,3}$ \\ Department of Plant Agriculture, Ontario Agricultural College, University of \\ Guelph, Vineland Campus, Ontario, LOR 2E0, Canada
}

Additional index words. peach, flower inhibition, fruit set, fruit size, gibberellic acid, hand thinning

\begin{abstract}
Adjusting the crop load of peaches [Prunus persica (L.) Batsch] by hand thinning is currently required to ensure marketable size of most cultivars grown in Ontario. A novel approach to adjust cropping by inhibiting flowering using gibberellic acid $\left(\mathrm{GA}_{3}\right)$ was tested in an orchard experiment in which $\mathbf{G A}_{3}$ was applied at 7,10 , and 13 weeks after full bloom to mature 'Redhaven' peach trees. Late $\mathbf{G A}_{3}$ treatments increased soluble solids concentration (SSC) in the season of application. A significant interaction between $\mathrm{GA}_{3}$ rate and time of application was observed on increased fruit firmness in the current season. Increasing rates of $\mathbf{G A}_{3}$ decreased flowering the following season in a quadratic fashion, resulting in a $41 \%$ to $90 \%$ diminished requirement for hand thinning. This translated into lower crop loads and yields for $\mathbf{G A}_{\mathbf{3}}$-treated trees at harvest compared with untreated control trees. However, $\mathbf{G A}_{3}$-treated trees had larger mean fruit size and improved fruit size distribution the year after $\mathbf{G A}_{3}$ application. Advanced fruit ripening was also evident by increased fruit SSC and decreased fruit firmness, likely an indirect effect of $\mathbf{G A}_{3}$ on crop load. $\mathbf{G A}_{3}$ application timing significantly increased overall tree growth measured by the changes in trunk cross-sectional area.
\end{abstract}

Peach (Prunus persica) cultivars grown in Ontario set heavy crops. A significant amount of hand thinning at the time of pit hardening $-\approx 45$ to $50 \mathrm{~d}$ after full bloom (DAFB) is needed to ensure fruit reach marketable size. However, hand thinning is costly and generally requires between 100 to $500 \mathrm{~h} / \mathrm{ha}$ depending on tree vigor, age and size, flower production, thinning intensity, and cultivar (Clanet et al., 1979; Southwick et al., 1996). Currently, the average labor cost for hand thinning peaches in Ontario is estimated to be $\$ 1057 /$ ha (Slingerland and Molenhuis, 2003).

Gibberellic acid $\left(\mathrm{GA}_{3}\right)$, applied the previous growing season, is known to reduce flower bud density by inhibiting flower initiation in Prunus species (Bradley and Crane, 1960; Byers et al., 1990; Edgerton, 1966; Painter and Stembridge, 1972; Southwick et al., 1995). Reducing flower initiation has been proposed as an alternative strategy to hand thinning (Corgan and Widmoyer, 1971; Garcia-Pallas et al., 2001; Southwick et al., 1997). Research by Taylor and GeislerTaylor (1998) demonstrated that the cultivar as well as the timing and concentration of the $\mathrm{GA}_{3}$ application all influence the extent to which flowering is inhibited. In regions where the risk of spring frost and winter injury to flower buds is low, reductions by $80 \%$ to $90 \%$ can be achieved without

Received for publication 11 Apr. 2006. Accepted for publication 14 July 2006.

${ }^{1}$ Research associate.

${ }^{2}$ Assistant professor, Tree Fruit Physiology.

${ }^{3}$ To whom reprint requests should be addressed. e-mail jcline@uoguelph.ca. affecting cropping potential (Dorsey and McMunn, 1944).

Market demand for large fruit and desire by producers to decrease labor costs have increased the impetus to find a suitable chemical thinning agent to thin peaches. Thus, the application of gibberellic acid to reduce flower density, and consequently crop loads, is of commercial interest to the peach and nectarine industry. Published data on the response of peach to flower bud inhibition in Ontario, where $75 \%$ of the Canadian peach industry is concentrated, is lacking. The objective of this study was to determine the influence of concentration and time of foliar $\mathrm{GA}_{3}$ applications on flower inhibition in 'Redhaven' peaches.

\section{Materials and Methods}

A 2-year experiment was conducted beginning in 2002 on 9-year-old 'Redhaven' peach trees growing in a research orchard at the University of Guelph, Vineland, Ontario

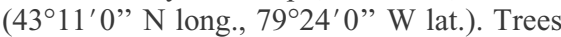
were spaced $5.0 \mathrm{~m}$ within rows and $6.0 \mathrm{~m}$ between rows (333 trees/ha), trained to a free standing open vase, and managed according to standard practices for Ontario (Anonymous, 2004).

Fifteen treatments were applied to single trees in a randomized complete block design with five replications. Spray treatments were applied with a hand gun (Green Garde JD9C; Rittenhouse, St. Catharines, Ontario) at a volume of $3330 \mathrm{~L} \cdot \mathrm{ha}^{-1}(\approx 10 \mathrm{~L} /$ tree $)$. Experimental units received one of the following treatments: $0,50,100,200$, or $400 \mathrm{mg} \cdot \mathrm{L}^{-1}$ gibberellic acid $\left(\mathrm{GA}_{3}\right)$, (Ralex formulation; Valent BioSciences Corporation, Libertyville, Ill.) plus $0.1 \%$ (v/v) Regulaid adjuvant (Kalo Inc., Overland Park, Kan.). Sprays were applied at 3-week intervals during the growing season beginning at 7, 10, and 13 weeks after full bloom (WAFB) corresponding to the calendar dates of 28 June, 16 July, and 7 Aug., respectively. Full bloom occurred on 8 May 2002. A hand-thinned control treatment was included for comparison purposes. Fruit were thinned on 20 June or $43 \mathrm{~d}$ after full bloom (DAFB) to a target spacing of 15 to $20 \mathrm{~cm}$ between fruits. Fruit were harvested on 15 Aug. and again on 26 Aug. based on a similar background color. Total yield and the number of fruit harvested per tree were recorded. On the second harvest, fruit were categorized as mature or immature (based on background color and suture filling) and the number and weight of each group recorded. On the first harvest date, fruit firmness and SSC were measured on a random sample of 10 fruit per tree free of defects and similar in maturity. After a 2-mm tangential section of skin was removed from the equator of the fruit, flesh firmness was measured using a penetrometer (model FT 327; Lake City Technical Products, Kelowna, British Columbia) equipped with a 7.9$\mathrm{mm}$ probe on two sides of each fruit at $\approx 90^{\circ}$ from the suture. Soluble solids were measured using a digital refractometer (Abbe Model 10,450; American Optical Corporation, Buffalo, N.Y.) from a composite sample of juice expressed while measuring fruit firmness. Blush and background color were also recorded on the same 10 fruits using a tristimulus colorimeter (Minolta CR-300; Minolta, Toronto).

To assess the treatment effect on flowering the following year, five branches per tree, ranging from 2.5 to $3.5 \mathrm{~cm}$ diameter and situated between 1.0 and $2.0 \mathrm{~m}$ above the ground, were tagged at bloom, and the number of flower buds recorded. The length of extension shoot growth on the marked branches was also measured at bloom, and the number of blossoms per branch was counted. All treated trees were hand thinned 59 DAFB (21 July) in 2003 and the number and weight of fruit removed were recorded. Final fruit set was determined on the same branches after natural abscission. The number of nodes per limb was counted on 17 June. Fruit were harvested on 22 Aug., and fruit were hand sorted into two groups (mature and immature) based on background color. The number and weight in each group were recorded from which mean fruit size was calculated. A random subsample of $\approx 5.5$ $\mathrm{kg}$ fruit per tree was used to determine fruit size distribution based on the following minimum size categories: $\leq 61,64,67,70$, 73 , and $\geq 76 \mathrm{~mm}$ in diameter. Fruit firmness and SSC were measured on a sample of 20 randomly selected fruit per tree free of defects. Fruit firmness was measured using an electronic penetrometer (Fruit Texture Analyzer, model GS-14; GUSS, South Africa). Fruit color was determined on both sides of 
20 fruit per tree using the same procedure as in 2002 as was SSC.

Tree growth was determined by measuring trunk circumference $30 \mathrm{~cm}$ above the union when the trees were dormant at the start and at the end of each growing season. Total shoot growth was measured in the autumn of 2003 on five tagged branches per tree (same as those used to determine fruit set in 2002).

Fisher's protected analysis of variance using PROC GLM (SAS; SAS Institute, Cary, N.C.) was conducted on the measured and calculated parameters. In the absence of significant treatment interaction, mean separation was performed using least significant difference. When significant treatment interaction existed, each treatment combination was analyzed separately. Orthogonal regression partitions were performed to evaluate the type of regression followed by estimate of the regression parameters. A multiple regression model was evaluated for most of the dependent variables plotted against the independent $\mathrm{GA}_{3}$ rate and application timing variables.

\section{Results and Discussion}

Current season response to $\mathrm{GA}_{3}$. In 2002 , no phytotoxicity was observed after the $\mathrm{GA}_{3}$ sprays were applied. No significant $\mathrm{GA}_{3}$ rate or timing effects on total yield, total number of fruit harvested, fruit maturity, crop density (data not shown), yield efficiency, and mean fruit size were observed in the year of $\mathrm{GA}_{3}$ application (Table 1). Clanet et al. (1979), and Southwick et al. $(1995,1997)$ found that $\mathrm{GA}_{3}$ sprays to the trees resulted in a reduction in cropping for two consecutive years in peach and other Prunus species. In the present study, total yield and yield efficiency were similar between the $\mathrm{GA}_{3}$-treated trees and the trees that were hand thinned. $\mathrm{GA}_{3}$ sprays applied at seven and 10 WAFB significantly increased SSC in comparison with sprays applied at 13 WAFB (Table 1), indicating a significant timing effect of $\mathrm{GA}_{3}$ on SSC in the year of application. There was also a significant interaction between $\mathrm{GA}_{3}$ rate and timing on fruit firmness (Fig. 1). Increasing rates of $\mathrm{GA}_{3}$ increased fruit firmness, but the effect diminished the closer applications were made to harvest.

No significant difference in ground color chromaticity $\left(\mathrm{C}^{*}\right)$ (McGuire, 1992) between treated trees and untreated controls was observed (Table 2). The increase in background hue angle suggested slightly retained yellow color development for trees receiving 100 to $400 \mathrm{mg} \cdot \mathrm{L}^{-1} \mathrm{GA}_{3}$. Both $\mathrm{GA}_{3}$ rate and time of application were found to interact to influence ground color $\mathrm{L}^{*}$ values; trees treated with $100 \mathrm{mg} \cdot \mathrm{L}^{-1} \mathrm{GA}_{3}$ at seven WAFB had fruit with significantly higher $\mathrm{L}^{*}$ values, which means fruit were brighter and therefore were more attractive. Blush color was also improved - more intense and redder for fruit harvested from $\mathrm{GA}_{3}$-treated tress as indicated by fruit chromaticity and hue angle values. Although fruit color differences were recorded after $\mathrm{GA}_{3}$ applications, these

Table 1. Effect of $\mathrm{GA}_{3}$ rate and timing on total number of fruit per tree, yield, and fruit quality of 'Redhaven' peach trees in the year of application (2002).

\begin{tabular}{|c|c|c|c|c|c|}
\hline Treatment & $\begin{array}{l}\text { Total number } \\
\text { of fruit/tree }\end{array}$ & $\begin{array}{c}\text { Total yield/tree } \\
(\mathrm{kg})\end{array}$ & $\begin{array}{l}\text { Yield efficiency } \\
\left(\mathrm{kg} / \mathrm{cm}^{2} \text { TCSA }\right)\end{array}$ & $\begin{array}{l}\text { Mean fruit } \\
\text { wt }(\mathrm{g})\end{array}$ & $\begin{array}{l}\text { Soluble solids } \\
\text { concn }(\%)\end{array}$ \\
\hline \multicolumn{6}{|c|}{ Rate of $\mathrm{GA}_{3}\left(\mathrm{mg} \cdot \mathrm{L}^{-1}\right)$} \\
\hline 0 & 402 & 54 & 0.48 & 142 & 11.3 \\
\hline 50 & 436 & 59 & 0.56 & 138 & 11.4 \\
\hline 100 & 507 & 69 & 0.55 & 135 & 11.4 \\
\hline 200 & 492 & 60 & 0.49 & 129 & 11.4 \\
\hline 400 & 453 & 56 & 0.47 & 124 & 11.6 \\
\hline Significance $^{z}$ & NS & NS & NS & NS & NS \\
\hline LSD $P=0.05$ & 145 & 16 & 0.11 & 18 & 0.5 \\
\hline$P$ value & 0.6549 & 0.4940 & 0.3581 & 0.3004 & 0.7314 \\
\hline \multicolumn{6}{|c|}{ Timing (WAFB) ${ }^{\mathrm{y}}$} \\
\hline 7 & 422 & 56 & 0.50 & 134 & $11.7 \mathrm{a}^{\mathrm{x}}$ \\
\hline 10 & 469 & 60 & 0.54 & 131 & $11.6 \mathrm{a}$ \\
\hline 13 & 484 & 64 & 0.49 & 135 & $11.0 \mathrm{~b}$ \\
\hline Significance & NS & NS & NS & NS & $* * *$ \\
\hline LSD $P=0.05$ & 112 & 13 & 0.09 & 14 & 0.4 \\
\hline$P$ value & 0.5642 & 0.4817 & 0.4231 & 0.8713 & 0.0007 \\
\hline \multicolumn{6}{|c|}{ Interaction rate vs. timing } \\
\hline Significance & NS & NS & NS & NS & NS \\
\hline$P$ value & 0.9052 & 0.784 & 0.8496 & 0.9204 & 0.6168 \\
\hline
\end{tabular}

${ }^{\mathrm{z}}$ Mean separation within columns by LSD at $P=0.05$.

${ }^{\mathrm{y}}$ Weeks after full bloom.

${ }^{x}$ Means with the same letter are not significantly different at $P=0.05,0.01$, or 0.001 , respectively. NS,*,******N Nonsignificant or significant differences at $P=0.05,0.01$, or 0.001 , respectively.

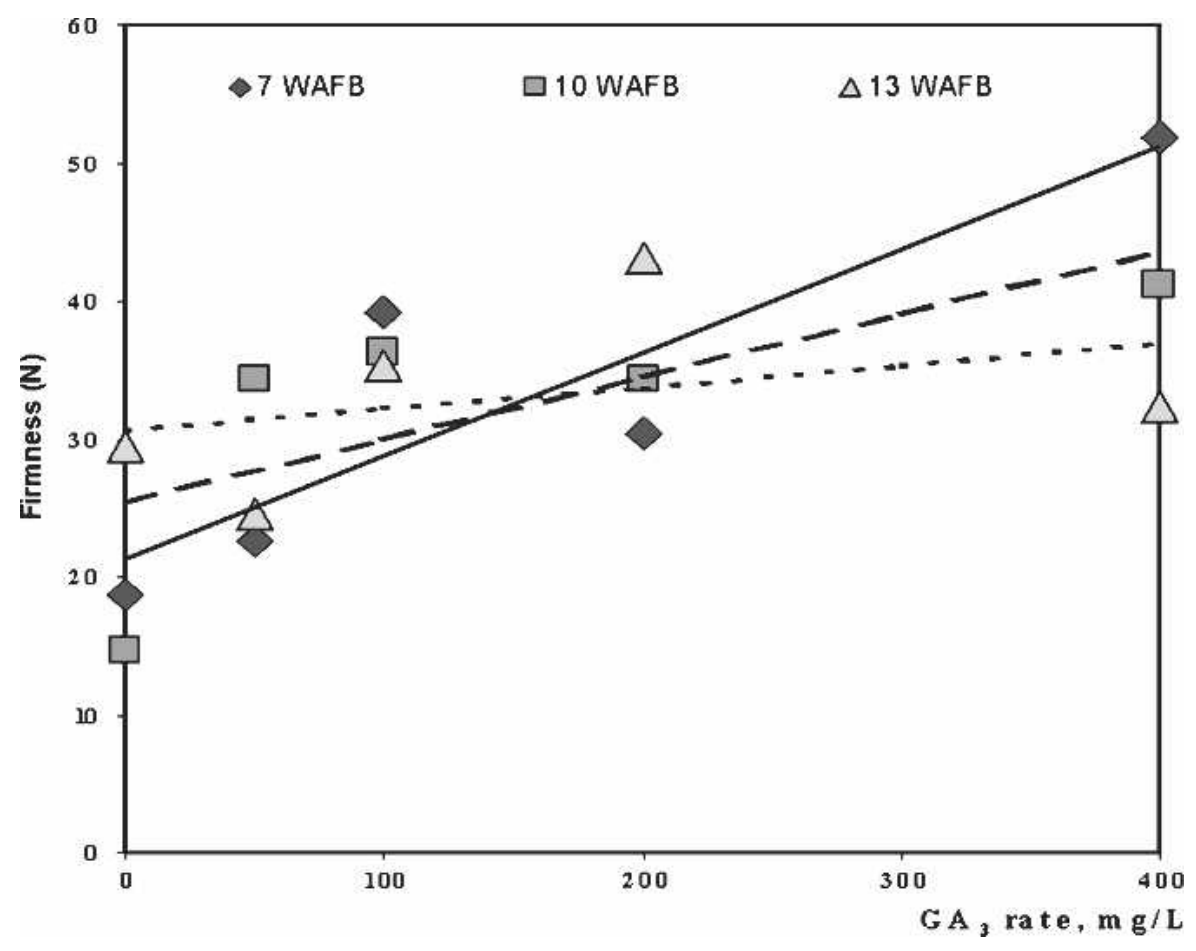

Fig. 1. Effect of $\mathrm{GA}_{3}$ rate and timing on fruit firmness of 'Redhaven' peach in the season of $\mathrm{GA}_{3}$ application (2002). Regression equations are: $Y_{7 \mathrm{WAFB}}=21.291+0.075 \mathrm{x} ; \mathrm{Y}_{10 \mathrm{WAFB}}=25.309+0.0456 \mathrm{x}$; $\mathrm{Y}_{13 \mathrm{WAFB}}=30.503+0.0162 \mathrm{x}$.

differences can be considered minor and were indistinguishable with the naked eye. Southwick et al. (1997) and Southwick and Fritts (1995) reported a similar fruit color response of $\mathrm{GA}_{3}$-treated vs. untreated stone fruits; however, in both studies, color was measured visually rather than quantitatively. Although $\mathrm{GA}_{3}$-treated fruit were firmer, their enhanced blush and background color indicates that fruit maturity was slightly advanced in comparison with untreated fruits. These results contradict with those of Monge et al. (1994), who found that early applications of $\mathrm{GA}_{3}$ to 'Redhaven' trees negatively affected fruit growth and quality during the current growing season.

Response to $\mathrm{GA}_{3}$ in the season after treatment. Gibberellic acid applied in 2002 significantly decreased the flower bud density in 2003 (Fig. 2). However, there was a significant interaction between $\mathrm{GA}_{3}$ rate and timing on flower bud density, which decreased in a curvilinear pattern with increasing rates of $\mathrm{GA}_{3}$. Increasing $\mathrm{GA}_{3}$ rates decreased flower 
Table 2. Effect of $\mathrm{GA}_{3}$ rate and timing on fruit color of 'Redhaven' peaches in the year of application (2002).

\begin{tabular}{|c|c|c|c|c|c|c|}
\hline \multirow[b]{2}{*}{ Treatment } & \multicolumn{3}{|c|}{ Ground color } & \multicolumn{3}{|c|}{ Blush color } \\
\hline & $\mathrm{L}^{*}$ & $\begin{array}{c}\text { Chroma } \\
\left(C^{*}\right)\end{array}$ & $\begin{array}{c}\text { Hue angle } \\
\text { (Ho) }\end{array}$ & $\mathrm{L}^{*}$ & $\begin{array}{c}\text { Chroma } \\
\left(\mathrm{C}^{*}\right)\end{array}$ & $\begin{array}{l}\text { Hue angle } \\
\text { (Ho) }\end{array}$ \\
\hline \multicolumn{7}{|c|}{ Rate of $\mathrm{GA}_{3}\left(\mathrm{mg} \cdot \mathrm{L}^{-1}\right)$} \\
\hline 0 & 64.9 & 37.9 & 68.4 & 39.6 & 26.2 & 25.0 \\
\hline 50 & 64.8 & 37.3 & 68.2 & 39.4 & 25.5 & 23.3 \\
\hline 100 & 67.6 & 41.2 & 74.7 & 39.7 & 27.9 & 25.4 \\
\hline 200 & 66.5 & 37.6 & 71.4 & 40.1 & 24.8 & 23.9 \\
\hline 400 & 66.4 & 37.8 & 73.2 & 38.3 & 27.9 & 23.8 \\
\hline Significance & $* * *$ & NS & $* * *$ & NS & $* *$ & $*$ \\
\hline LSD $P=0.05$ & 1.1 & 3.5 & 2.2 & 1.3 & 1.7 & 1.4 \\
\hline$P$ value & $<0.0001$ & 0.1700 & $<0.0001$ & 0.0680 & 0.0019 & 0.0154 \\
\hline \multicolumn{7}{|c|}{ Timing $(\mathrm{WAFB})^{\mathrm{z}}$} \\
\hline 7 & 67.1 & 38.1 & 73.3 & 39.9 & 25.5 & 24.2 \\
\hline 10 & 65.6 & 39.6 & 70.2 & 38.9 & 25.9 & 23.8 \\
\hline 13 & 65.6 & 37.3 & 70.1 & 39.4 & 27.5 & 24.7 \\
\hline Significance & $* * *$ & NS & $* * *$ & NS & $* *$ & NS \\
\hline LSD $P=0.05$ & 0.8 & 2.7 & 1.7 & 1.0 & 1.3 & 1.1 \\
\hline$P$ value & 0.0007 & 0.2283 & 0.0001 & 0.1067 & 0.0059 & 0.2670 \\
\hline \multicolumn{7}{|c|}{ Interaction rate vs. timing } \\
\hline Significance & $* * *$ & NS & $* * *$ & $* * *$ & $* * *$ & $*$ \\
\hline$P$ value & 0.0003 & 0.1210 & $<0.0001$ & $<0.0001$ & $<0.0001$ & 0.0285 \\
\hline
\end{tabular}

${ }^{\mathrm{z}}$ Weeks after full bloom.

NS, $, * * *, * * *$ Nonsignificant or significant differences at $P=0.05,0.01$, or $P=0.001$, respectively. Mean separation within columns by LSD at $P=0.05$.

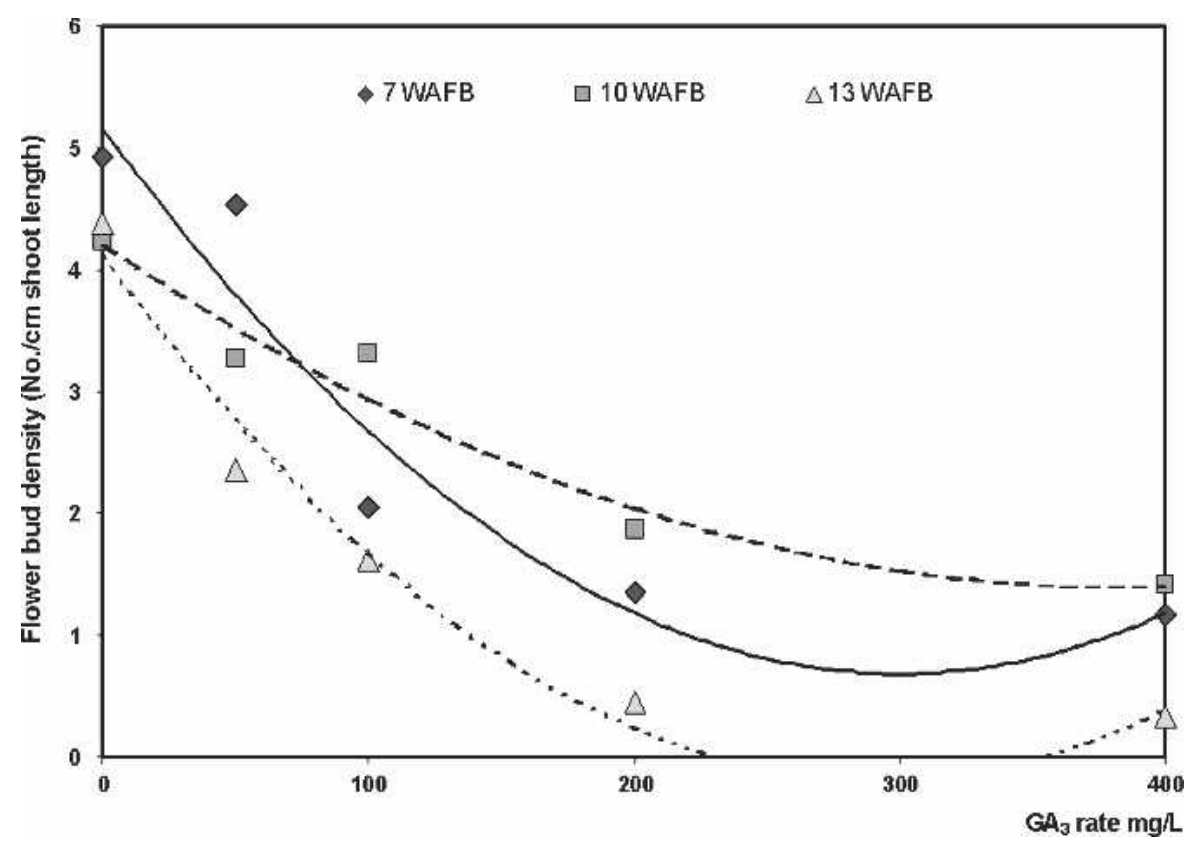

Fig. 2. Effect of $\mathrm{GA}_{3}$ rate and timing on flower bud density of 'Redhaven' peach in the season after application (2003). Regression equations are: $\mathrm{Y}_{7 \mathrm{WAFB}}=5 \mathrm{E}-06 \mathrm{x}^{2}-0.00298 \mathrm{x}+5.1638 ; \mathrm{Y}_{10 \mathrm{WAFB}}=$ $2 \mathrm{E}-05 \mathrm{x}^{2}-0.0146 \mathrm{x}+4.2092 ; \mathrm{Y}_{13 \mathrm{WAFB}}=5 \mathrm{E}-05 \mathrm{x}^{2}-0.0293 \mathrm{x}+4.1042$.

density ranging from $25 \%$ to $75 \% . \mathrm{GA}_{3}$ at either 200 or $400 \mathrm{mg} \cdot \mathrm{L}^{-1}$ had a similar effect on the reduction in flower density. Clanet et al. (1979), Southwick et al. (1997), and Garcia-Pallas et al. (2001) found that summer applications of $\mathrm{GA}_{3}$ to peach and other Prunus species reduced cropping the subsequent growing season. Southwick et al. (1995) found a linear reduction in flower numbers on 'Loadel' peach trees with increasing $\mathrm{GA}_{3}$ concentrations from 50 to 120 $\mathrm{mg} \cdot \mathrm{L}^{-1}$ when applied 13 WAFB. However, less flower inhibition was obtained when applications were made 16 WAFB, indicating a phenologic sensitivity to $\mathrm{GA}_{3}$ spray. In the present study, treatments applied at 13 WAFB inhibited flowering the greatest (Fig. 2 ) in comparison with sprays applied 7 and 10 WAFB. These data are consistent with those reported elsewhere (Byers et al., 1990; Ward, 1993). Painter and Stembridge (1972) found that high concentrations of $\mathrm{GA}_{3}$, applied late in the summer, may kill flower buds, which could be considered one mechanism of how thinning was achieved in the present study.

Fruit density after fruit set, expressed as the number of fruit per unit shoot length, decreased in a quadratic fashion with increasing rates of $\mathrm{GA}_{3}$ up to $200 \mathrm{mg} \cdot \mathrm{L}^{-1}$. $\mathrm{GA}_{3}$ at $400 \mathrm{mg} \cdot \mathrm{L}^{-1}$ provided no additional reduction in fruit density (Table 3 ). In general, $\mathrm{GA}_{3}$-treated trees set two to three times fewer fruit compared with untreated controls. Garcia-Pallas et al. (2001) found a linear decrease in fruit set of 'Crimson Gold' nectarine with increasing rates of $\mathrm{GA}_{3}$ rate of up to $100 \mathrm{mg} \cdot \mathrm{L}^{-1}$. Treatment timing significantly affected fruit set in the present study. Treatments made at seven WAFB had a moderate effect on reducing fruit set, whereas treatments made at 10 WAFB were the least effective. In contrast, treatments applied at 13 WAFB had the greatest effect.

$\mathrm{GA}_{3}$ applications made the previous season reduced the number of vegetative and reproductive buds toward the basal region of these shoots, resulting in "blind wood." There was a significant interaction between the rate and timing of $\mathrm{GA}_{3}$ applications on the reduction of node density (Table 3 ). Increasing rates of $\mathrm{GA}_{3}$ resulted in a linear reduction in node density. Hull and Lewis (1959) found that sprays of $\mathrm{GA}_{3}$ resulted in the formation of blind wood in the middle region of extension shoots the next season. Taylor and Geisler-Taylor (1998) observed a reduction in the number of viable buds per unit shoot length on 'Cresthaven' trees when treated with 50 or $65 \mathrm{mg} \cdot \mathrm{L}^{-1} \mathrm{GA}_{3}$, but did not observe this for 'Redhaven'.

The rate of $\mathrm{GA}_{3}$ and time of application significantly affected the number and weight of fruit that required thinning (Table 3 ). The amount of hand thinning required to adjust the crop load to an acceptable level was reduced by $41 \%$ and $90 \%$ for $50 \mathrm{mg} \cdot \mathrm{L}^{-1}$ $\mathrm{GA}_{3}$ and $400 \mathrm{mg} \cdot \mathrm{L}^{-1} \mathrm{GA}_{3}$ treatments, respectively, compared with the hand-thinned treatment. The relationship between $\mathrm{GA}_{3}$ rate and the level of hand thinning followed a quadratic pattern, in which rates above $200 \mathrm{mg} \cdot \mathrm{L}^{-1}$ provided little additional benefit in reducing the requirement for hand thinning. Applications made at 10 WAFB were the least effective for reducing crop loads in contrast to applications made late in the season-at 13 WAFB. Southwick et al. (1995) reported that $\mathrm{GA}_{3}$ sprays applied in June (at 13 WAFB) and early July (16 WAFB) resulted in a significant reduction in hand-thinning requirements the next year with no thinning required from $\mathrm{GA}_{3}$ spray applied at 13 WAFB. In the present study, a significant interaction between the rate of $\mathrm{GA}_{3}$ and time of application was observed for the mean weight of thinned fruitlets the year after application (Table 3). Higher rates of $\mathrm{GA}_{3}$ applied 13 WAFB resulted in the smallest mean weight, whereas treatments made seven WAFB had no influence on the weight of thinned fruit regardless of the rate of $\mathrm{GA}_{3}$ applied. Southwick et al. (1997) found that greater fruit weight of apricots (cv. Patterson) was evident at stage II of fruit development after treatment of $100 \mathrm{mg} \cdot \mathrm{L}^{-1} \mathrm{GA}_{3}$ applied on 1 June in the previous year. Fruit density at harvest was reduced by $20 \%$ to $60 \%$ for $\mathrm{GA}_{3}$-treated trees in comparison with the untreated control trees (Fig. 3). However, a significant interaction between $\mathrm{GA}_{3}$ rate and timing existed. 
Table 3. Carryover effect of $\mathrm{GA}_{3}$ rate and timing on percentage of mature and immature yield, button yield, and mean full size of 'Redhaven' peach trees in the year after application (2003).

\begin{tabular}{|c|c|c|c|c|c|c|c|}
\hline Treatment & $\begin{array}{c}\text { Fruit density at set } \\
\text { (no. fr./m shoot length) }\end{array}$ & $\begin{array}{c}\text { Node density } \\
\text { (no./m shoot length) }\end{array}$ & $\begin{array}{c}\text { Wt of } \\
\text { thinned fruit per } \\
\text { tree }(\mathrm{kg})\end{array}$ & $\begin{array}{c}\text { Mean } \\
\text { thinned fruit } \\
\text { wt }(\mathrm{g})\end{array}$ & $\begin{array}{c}\text { Number of } \\
\text { thinned fruit } \\
\text { per tree }\end{array}$ & $\begin{array}{c}\text { Total number } \\
\text { of fruit } \\
\text { per tree }\end{array}$ & $\begin{array}{l}\text { Mean } \\
\text { fruit } \\
\text { wt }(g)\end{array}$ \\
\hline \multicolumn{8}{|c|}{$\overline{\text { Rate of } \mathrm{GA}_{3}\left(\mathrm{mg} \cdot \mathrm{L}^{-1}\right)}$} \\
\hline 0 & $0.23 \mathrm{a}^{\mathrm{z}}$ & 47 & $10 \mathrm{a}$ & 29 & $362 \mathrm{a}$ & $561 \mathrm{a}$ & $111 \mathrm{c}$ \\
\hline 50 & $0.19 \mathrm{~b}$ & 41 & $7 \mathrm{~b}$ & 32 & $216 \mathrm{~b}$ & $419 b$ & $125 \mathrm{bc}$ \\
\hline 100 & $0.15 \mathrm{c}$ & 39 & $4 \mathrm{c}$ & 29 & $132 \mathrm{bc}$ & $302 \mathrm{c}$ & $155 \mathrm{ab}$ \\
\hline 200 & $0.09 \mathrm{~d}$ & 32 & $2 \mathrm{~d}$ & 19 & $51 \mathrm{~cd}$ & $180 \mathrm{~d}$ & $182 \mathrm{a}$ \\
\hline 400 & $0.08 \mathrm{~d}$ & 28 & $1 \mathrm{~d}$ & 14 & $38 \mathrm{~d}$ & $132 \mathrm{~d}$ & $176 \mathrm{a}$ \\
\hline \multicolumn{8}{|l|}{ Timing $(\mathrm{WAFB})^{\mathrm{y}}$} \\
\hline 7 & $0.15 \mathrm{a}$ & 35 & $4 \mathrm{~b}$ & 24 & $150 \mathrm{ab}$ & 314 & $139 \mathrm{~b}$ \\
\hline 10 & $0.18 \mathrm{a}$ & 41 & $6 \mathrm{a}$ & 27 & 199 a & 355 & $141 \mathrm{~b}$ \\
\hline 13 & $0.12 \mathrm{~b}$ & 35 & $4 \mathrm{~b}$ & 22 & $123 \mathrm{~b}$ & 276 & $170 \mathrm{a}$ \\
\hline \multicolumn{8}{|l|}{ Probability of F test } \\
\hline Rate of $\mathrm{GA}_{3}(\mathrm{R})$ & $\mathrm{Q}^{* * *}$ & $\mathrm{Q}^{* * *}$ & $\mathrm{Q}^{* * * *}$ & $\mathrm{~L}^{* * * *}$ & $\mathrm{Q}^{* * * *}$ & $\mathrm{Q}^{* * *}$ & $\mathrm{Q}^{* *}$ \\
\hline Timing $(\mathrm{T})$ & $\mathrm{L}^{* * *}$ & $\mathrm{~L}^{* *}$ & $\mathrm{~L}^{*}$ & NS & $\mathrm{L}^{*}$ & NS & $\mathrm{L}^{* *}$ \\
\hline Interaction $\left(\mathrm{R}^{*} \mathrm{~T}\right)$ & NS & $\mathrm{L}^{* *}$ & NS & $\mathrm{L}^{* *}$ & NS & NS & NS \\
\hline
\end{tabular}

${ }^{2}$ Means with the same letter are not significantly different at $P=0.05, P=0.01$, or $P=0.001$, respectively.

${ }^{\mathrm{y}}$ Weeks after full bloom of 'Redhaven' peach trees in the year after application (2003).

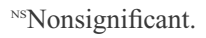

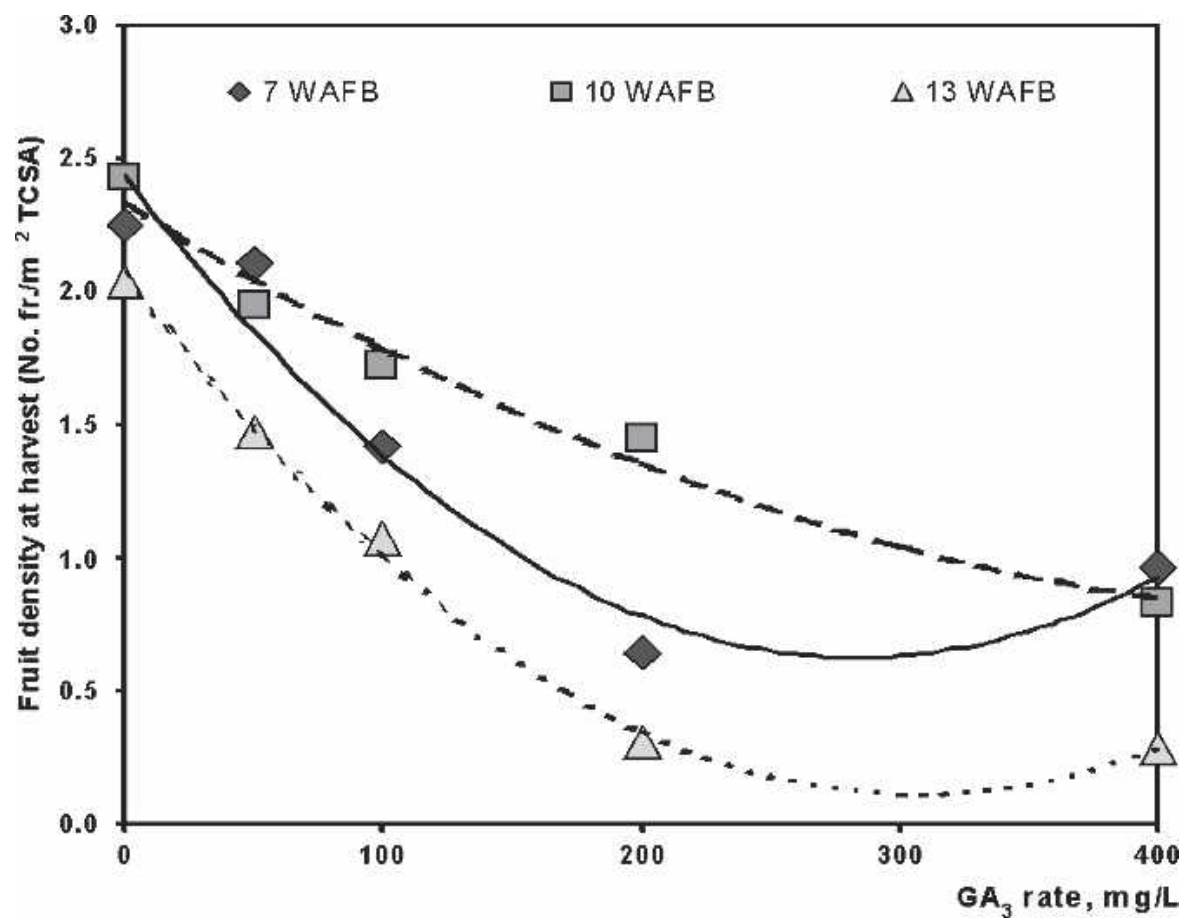

Fig. 3. Effect of $\mathrm{GA}_{3}$ rate and timing on fruit density at harvest of 'Redhaven' peach in the season after application (2003). Regression equations are: $\mathrm{Y}_{7 \mathrm{WAFB}}=2.4337-0.0128 \mathrm{x}+2 \mathrm{E}-05 \mathrm{x}^{2} ; \mathrm{Y}_{10 \mathrm{WAFB}}=$ $2.3395-0.0061 \mathrm{x}+6 \mathrm{E}-06 \mathrm{x}^{2} ; \mathrm{Y}_{13 \mathrm{WAFB}}=2.0608-0.0127 \mathrm{x}+2 \mathrm{E}-05 \mathrm{x}^{2}$.

Increasing the rate of $\mathrm{GA}_{3}$ was found to reduce the total number of fruit per tree at harvest (Table 3). Southwick et al. (1997), and Garcia-Pallas et al. (2001) also observed fewer fruit number per tree at harvest after $\mathrm{GA}_{3}$ treatments made during the previous growing season.

$\mathrm{GA}_{3}$ rate and timing influenced mean fruit weight at harvest the year after $\mathrm{GA}_{3}$ applications (Table 3). According to Weinberger (1941) and Ho (1988), early reduction of flower buds and fruit by bloom thinning maximizes the ability of the tree to size fruit. Southwick and Glozer (2000), Southwick and Fritts (1995), and Garcia-Pallas et al., (2001) all reported increased fruit size after $\mathrm{GA}_{3}$ application in Prunus species. In the present study, a $64 \%$ increase in mean fruit size, especially from treatments made in August, demonstrates the potential of $\mathrm{GA}_{3}$ to improve fruit size and to adjust the crop density to a more favorable level.

There was a significant treatment interaction between $\mathrm{GA}_{3}$ rate and timing on total yield per tree (Fig. 4). Higher $\mathrm{GA}_{3}$ rates, applied at $13 \mathrm{WAFB}$, resulted in a linear decrease in yield per tree, whereas treatments applied at 10 WAFB resulted in the highest yield per tree. Garcia-Pallas et al. (2001) also reported a linear decrease in yield of 'Crimson Gold' nectarine with increasing $\mathrm{GA}_{3}$ rates.

$\mathrm{GA}_{3}$ applications advanced fruit maturity the year after application (Table 4), especially when applied late in the season.
The mean mature fruit weight at harvest increased in a quadratic fashion with increasing rates of $\mathrm{GA}_{3}$; fruit size peaked at $\approx 200$ $\mathrm{mg} \cdot \mathrm{L}^{-1} \mathrm{GA}_{3}$ and decreased beyond this rate. Fruit weight was also influenced by time of application. Fruit from trees treated with $\mathrm{GA}_{3}$ at 13 WAFB were $20 \%$ larger than fruit from trees treated earlier in the season. Furthermore, the percentage of immature fruit per tree at harvest decreased with increasing rates of $\mathrm{GA}_{3}$ sprays.

Increased button (small, pygmy) fruit formation was observed in response to $\mathrm{GA}_{3}$ on 'Redhaven' (Table 4). The seed of these fruit did not fill the pit cavity and remained on the trees until harvest. The number of button fruit per tree was about three times higher when $\mathrm{GA}_{3}$ application was made at 7 WAFB compared with the treatments made at 10 or 13 WAFB. The greatest number of button fruit per tree was observed at $200 \mathrm{mg} \cdot \mathrm{L}^{-1}$ $\mathrm{GA}_{3}$, whereas the number of button fruit per tree at $50 \mathrm{mg} \cdot \mathrm{L}^{-1} \mathrm{GA}_{3}$ was similar to the untreated control trees. Southwick et al. (1996), Byers and Lyons (1985), and Greene (2004) also reported a higher incidence of button fruit after chemical blossom thinning of peach and apple.

In addition to larger fruit size, the percentage of fruit with diameter $76 \mathrm{~mm}$ and larger was two to five times higher for $\mathrm{GA}_{3}$ treated trees (Table 5) compared with untreated hand-thinned control trees, and the increase was proportional to the increase of $\mathrm{GA}_{3}$ rate. There was a significant treatment interaction on fruit firmness at harvest in 2003 (Table 5). Rates of $200 \mathrm{mg} \cdot \mathrm{L}^{-1} \mathrm{GA}_{3}$ and applications made at 13 WAFB resulted in the softest fruit. Fruit maturity was advanced in trees treated with $\mathrm{GA}_{3}$, likely an indirect effect of $\mathrm{GA}_{3}$ on crop load. The rate and timing of $\mathrm{GA}_{3}$ also influenced fruit SSC at harvest in 2003, again likely an indirect effect on fruit size. Trees treated with high rates of $\mathrm{GA}_{3}$ and early applications resulted in fruit with the highest SSC.

Shoot length and number of shoots per branch were not significantly different between treatments (Table 6) in both years. 


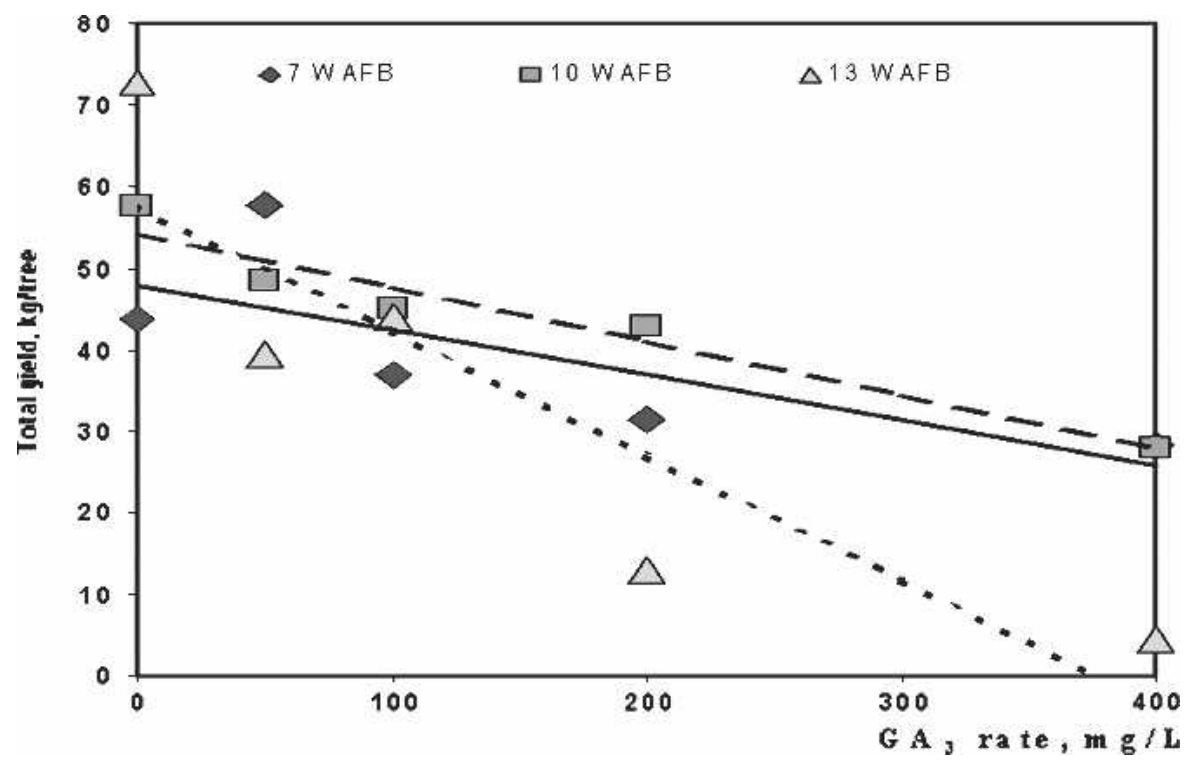

Fig. 4. Effect of $\mathrm{GA}_{3}$ rate and timing on total yield of 'Redhaven' peach in the season after application (2003). Regression equations are: $\mathrm{Y}_{7 \mathrm{WAFB}}=47.931-0.0553 \mathrm{x} ; \mathrm{Y}_{10 \mathrm{WAFB}}=54.313-0.066 \mathrm{x} ; \mathrm{Y}_{13 \mathrm{WAFB}}=$ $57.696-0.1531 x$
Application timing affected tree growth expressed as trunk cross-sectional area (TCSA) in 2002. In both years, $\mathrm{GA}_{3}$ rate of 200 $\mathrm{mg} \cdot \mathrm{L}^{-1}$ resulted in highest shoot length and shoot number. Trunk growth in 2003, as well as cumulative trunk growth, revealed differences in response to $\mathrm{GA}_{3}$ application timing. Treatments applied 13 WAFB enhanced trunk growth the greatest followed by applications made at seven WAFB, whereas the applications made at $10 \mathrm{WAFB}$ resulted in least amount of growth. Increased vegetative growth after $\mathrm{GA}_{3}$ treatments have been reported previously (Byers et al., 2003; GarciaPallas et al., 2001)

Several positive effects of $\mathrm{GA}_{3}$ applications were observed in the present study. Fruit quality was improved in the year of $\mathrm{GA}_{3}$ application. There appears to be wide window of opportunity to apply $\mathrm{GA}_{3}$, ranging from 7 to $13 \mathrm{WAFB}$, to selectively decrease flowering the next season. When this is accomplished, the requirement for hand thinning can be significantly reduced, resulting in increased labor and cost savings and

Table 4. Carryover effect of $\mathrm{GA}_{3}$ rate and timing on percentage of mature and immature yield, button yield, and mean fruit size.

\begin{tabular}{|c|c|c|c|c|c|c|}
\hline Treatment & $\begin{array}{l}\text { Percent mature } \\
\text { yield }(\%)\end{array}$ & $\begin{array}{c}\text { Mean wt of mature } \\
\text { fruit }(\mathrm{g})\end{array}$ & $\begin{array}{l}\text { Percent immature } \\
\text { yield }(\%)\end{array}$ & $\begin{array}{l}\text { Mean immature } \\
\text { fruit wt }(\mathrm{g})\end{array}$ & $\begin{array}{c}\text { Button fruit } \\
\text { yield per tree }(\mathrm{kg})\end{array}$ & $\begin{array}{c}\text { Number of button } \\
\text { fruit per tree }\end{array}$ \\
\hline \multicolumn{7}{|l|}{$\overline{\text { Rate of } \mathrm{GA}_{3}\left(\mathrm{mg} \cdot \mathrm{L}^{-1}\right)}$} \\
\hline 0 & $54 b^{z}$ & $136 \mathrm{~d}$ & $45 \mathrm{a}$ & 88 & 0.3 & 11 \\
\hline 50 & $72 \mathrm{a}$ & $148 \mathrm{~cd}$ & $27 \mathrm{~b}$ & 86 & 0.5 & 16 \\
\hline 100 & $71 \mathrm{a}$ & $175 \mathrm{bc}$ & $25 \mathrm{bc}$ & 76 & 2.1 & 67 \\
\hline 200 & $71 \mathrm{a}$ & $207 \mathrm{a}$ & $15 \mathrm{bc}$ & 74 & 4.5 & 143 \\
\hline 400 & $76 \mathrm{a}$ & $204 \mathrm{ab}$ & $13 \mathrm{c}$ & 59 & 3.0 & 99 \\
\hline \multicolumn{7}{|l|}{ Timing $(\mathrm{WAFB})^{\mathrm{y}}$} \\
\hline 7 & $61 \mathrm{~b}$ & $164 \mathrm{~b}$ & 30 & 78 & 3.9 & 126 \\
\hline 10 & $75 \mathrm{a}$ & $163 \mathrm{~b}$ & 22 & 79 & 1.3 & 42 \\
\hline 13 & $70 \mathrm{ab}$ & $196 \mathrm{a}$ & 23 & 73 & 1.3 & 40 \\
\hline \multicolumn{7}{|l|}{ Probability of F test } \\
\hline Rate of $\mathrm{GA}_{3}(\mathrm{R})$ & $\mathrm{L}^{*}$ & $\mathrm{Q}^{* *}$ & $\mathrm{Q}^{*}$ & $\mathrm{~L}^{*}$ & $\mathrm{~L}^{*}$ & $\mathrm{~L}^{*}$ \\
\hline Timing $(\mathrm{T})$ & $\mathrm{L}^{* *}$ & $\mathrm{~L}^{* *}$ & NS & NS & NS & NS \\
\hline Interaction $(\mathrm{R} * \mathrm{~T})$ & NS & NS & NS & $\mathrm{Q}^{*}$ & NS & NS \\
\hline
\end{tabular}

${ }^{\mathrm{z}}$ Means with the same letter are not significantly different at $P=0.05, P=0.01$, or $P=0.001$, respectively.

${ }^{y}$ Weeks after full bloom.

Ns Nonsignificant.

Table 5. Effect of $\mathrm{GA}_{3}$ rate and timing on fruit size distribution and fruit quality of 'Redhaven' peach trees in the year after application (2003).

\begin{tabular}{|c|c|c|c|c|c|c|c|c|}
\hline Treatment & $\begin{array}{l}\text { Percent fruit } \\
\text { with diam. } \\
61 \mathrm{~mm}\end{array}$ & $\begin{array}{l}\text { Percent fruit } \\
\text { with diam. } \\
64 \mathrm{~mm}\end{array}$ & $\begin{array}{l}\text { Percent fruit } \\
\text { with diam. } \\
67 \mathrm{~mm}\end{array}$ & $\begin{array}{l}\text { Percent fruit } \\
\text { with diam. } \\
70 \mathrm{~mm}\end{array}$ & $\begin{array}{l}\text { Percent fruit } \\
\text { with diam. } \\
73 \mathrm{~mm}\end{array}$ & $\begin{array}{l}\text { Percent fruit } \\
\text { with diam. } \\
76 \mathrm{~mm}\end{array}$ & $\begin{array}{l}\text { Firmness } \\
(\mathrm{N})\end{array}$ & $\begin{array}{c}\text { Soluble solids } \\
\text { concn }(\%)\end{array}$ \\
\hline \multicolumn{9}{|c|}{ Rate of $\mathrm{GA}_{3}\left(\mathrm{mg} \cdot \mathrm{L}^{-1}\right)$} \\
\hline 0 & 28 & 21 & $24 a^{x}$ & 4 & 11 & $12 \mathrm{c}$ & $38 \mathrm{a}$ & $10.5 \mathrm{c}$ \\
\hline 50 & 28 & 21 & $13 \mathrm{~b}$ & 3 & 9 & $27 \mathrm{bc}$ & $32 \mathrm{~b}$ & $11.2 \mathrm{bc}$ \\
\hline 100 & 15 & 14 & $14 \mathrm{~b}$ & 4 & 11 & $42 \mathrm{ab}$ & $27 \mathrm{c}$ & $10.9 \mathrm{bc}$ \\
\hline 200 & 5 & 7 & $11 \mathrm{~b}$ & 3 & 13 & $61 \mathrm{a}$ & $20 \mathrm{~d}$ & $11.5 \mathrm{ab}$ \\
\hline 400 & 8 & 8 & $9 b$ & 6 & 10 & $60 \mathrm{a}$ & $24 \mathrm{c}$ & $12.0 \mathrm{a}$ \\
\hline Significance $^{z}$ & NS & NS & * & NS & NS & $* * *$ & $* * *$ & $* *$ \\
\hline $\operatorname{LSD} P=0.05$ & 21 & 11 & 10 & 4 & 6 & 20 & 2 & 0.8 \\
\hline$P$ value & 0.0519 & 0.0574 & 0.0415 & 0.6068 & 0.6453 & $<0.0001$ & $<0.0001$ & 0.0054 \\
\hline \multicolumn{9}{|c|}{ Timing (WAFB) $)^{\mathrm{y}}$} \\
\hline 7 & 19 & 15 & 14 & 4 & 12 & 36 & $30 \mathrm{a}$ & 11.4 \\
\hline 10 & 20 & 16 & 14 & 3 & 10 & 37 & $30 \mathrm{a}$ & 11.3 \\
\hline 13 & 10 & 11 & 14 & 4 & 11 & 50 & $25 \mathrm{~b}$ & 11.1 \\
\hline Significance & NS & NS & NS & NS & NS & NS & $* * *$ & NS \\
\hline LSD $P=0.05$ & 16 & 9 & 7 & 3 & 4 & 16 & 2 & 0.6 \\
\hline$P$ value & 0.2728 & 0.5438 & 0.9680 & 0.8163 & 0.9033 & 0.0701 & $<0.0001$ & 0.9455 \\
\hline \multicolumn{9}{|c|}{ Interaction (rate vs. timing) } \\
\hline Significance & NS & NS & NS & NS & NS & NS & $* * *$ & NS \\
\hline$P$ value & 0.9397 & 0.8534 & 0.8330 & 0.1078 & 0.2251 & 0.8189 & $<0.0001$ & 0.8478 \\
\hline
\end{tabular}

${ }^{\mathrm{z}}$ Mean separation within columns by LSD at $P=0.05$.

${ }^{\mathrm{y}}$ Weeks after full bloom.

${ }^{\mathrm{x}}$ Means with the same letter are not significantly different at $P=0.05, P=0.01$, or $P=0.001$, respectively.

Ns,,$* * * * * * * N o n s i g n i f i c a n t$ and significant differences at $P=0.05,0.01$, and 0.001 , respectively. 
Table 6. Effect of $\mathrm{GA}_{3}$ rate and timing on the vegetative growth of 'Redhaven' peach trees in 2002-2003.

\begin{tabular}{|c|c|c|c|c|c|c|c|}
\hline \multirow[b]{2}{*}{ Treatment } & \multicolumn{3}{|c|}{2002} & \multicolumn{4}{|c|}{2003} \\
\hline & $\begin{array}{l}\text { Shoot length } \\
(\mathrm{cm} / \text { branch })\end{array}$ & $\begin{array}{l}\text { Number of fruiting } \\
\text { shoots per branch }\end{array}$ & $\begin{array}{l}\text { Trunk growth } \\
\left(\mathrm{cm}^{2} \text { TCSA) }\right.\end{array}$ & $\begin{array}{l}\text { Shoot length } \\
(\mathrm{cm} / \text { branch })\end{array}$ & $\begin{array}{l}\text { Number of fruiting } \\
\text { shoots per branch }\end{array}$ & $\begin{array}{l}\text { Trunk growth } \\
\left(\mathrm{cm}^{2} \text { TCSA) }\right.\end{array}$ & $\begin{array}{l}\text { Cumulative trunk } \\
\text { growth }\left(\mathrm{cm}^{2} \text { TCSA) }\right.\end{array}$ \\
\hline \multicolumn{8}{|c|}{ Rate of $\mathrm{GA}_{3}\left(\mathrm{mg} \cdot \mathrm{L}^{-1}\right)$} \\
\hline 100 & 298 & 15 & 11 & 184 & 18 & 18 & 29 \\
\hline 200 & 340 & 22 & 14 & 261 & 22 & 20 & 34 \\
\hline 400 & 335 & 13 & 13 & 198 & 18 & 18 & 32 \\
\hline$P$ value & 0.1640 & 0.2790 & 0.177 & 0.0053 & 0.1908 & 0.0514 & 0.0639 \\
\hline \multicolumn{8}{|c|}{ Timing (WAFB) ${ }^{y}$} \\
\hline 7 & 311 & 15 & $9 a^{x}$ & 202 & 20 & $14 \mathrm{a}$ & $23 \mathrm{a}$ \\
\hline 10 & 307 & 20 & $8 \mathrm{a}$ & 167 & 17 & $13 \mathrm{a}$ & $21 \mathrm{a}$ \\
\hline 13 & 335 & 14 & $16 \mathrm{~b}$ & 210 & 19 & $22 \mathrm{~b}$ & $38 \mathrm{~b}$ \\
\hline Significance & NS & NS & ** & NS & NS & ** & **** \\
\hline LSD $P=0.05$ & 33 & 7 & 4 & 47 & 3 & 5 & 9 \\
\hline
\end{tabular}

${ }^{\mathrm{z}}$ Mean separation within columns by LSD at $P=0.05$.

${ }^{\mathrm{y}}$ Weeks after full bloom.

${ }^{x}$ Means with the same letter are not significantly different at $P=0.05, P=0.01$, or $P=0.001$, respectively.

${ }^{\mathrm{N} N}$ Nonsignificant and significant differences at $P=0.05,0.01$, and 0.001 , respectively.

increased fruit size and quality, both within and the season after application. Because $\mathrm{GA}_{3}$ is a naturally occurring plant growth bioregulator synthesized in plants, and is registered for use in many other temperate fruit crops (e.g., grapes, cherries), it offers a safe, environmentally responsible, and organically improved (The OMRI Products List, 2006) compound that can be used commercially. Finally, in regions where there is a risk of spring frost or lack of winter chilling, a two-stage crop load strategy of partial flower inhibition using $\mathrm{GA}_{3}$ at rates ranging from 50 to $150 \mathrm{mg} \cdot \mathrm{L}^{-1}$ combined with follow-up hand thinning (the year after application at the time of natural fruit abscission) would reduce the risk of overthinning. This two-stage conservative approach to the crop load management of peaches could be adjusted as experience is gained using gibberellic acid.

\section{Literature Cited}

Anonymous. 2004. Fruit production recommendation 2004-2005. Publication 360. Ontario Ministry of Agriculture, Food and Rural Affairs, Toronto.

Bradley, M.V. and J.C. Crane. 1960. Gibberellininduced inhibition of bud development in some species of Prunus. Science 131:825-826.

Byers, R.E., D.H. Carbaugh, and C.N. Presley. 1990. The influence of bloom thinning and $\mathrm{GA}_{3}$ sprays on flower bud numbers and distribution in peach trees. J. Hort. Sci. 65:143-150.

Byers, R.E., G. Costa, and G. Vizzotto. 2003. Flower and Fruit thinning of peach and other Prunus. Hort. Rev. (Amer. Soc. Hort. Sci.) 28:351-392.

Byers, R.E. and C.G. Lyons, Jr. 1985. Peach flower thinning and possible sites of action of desiccating chemicals. J. Amer. Soc. Hort. Sci. 110:662-667.

Clanet, H., J.C. Salles, and C. Pinet. 1979. L'eclairssage des fleurs ou des jeunes fruits du pecher. Arboricult. Fruitere. 395:53-60

Corgan, J.N. and F.B. Widmoyer. 1971. The effects of gibberellic acid on flower differentiation date of bloom, and cold hardiness of peach. Proc. Amer. Soc. Hort. Sci. 96:54-57.

Dorsey, M.J. and R.L. McMunn. 1944. Treeconditioning the peach crop. Univ. Illinois Agr. Expt. Sta. Bul. 507.

Edgerton, L.J. 1966. Some effects of gibberellin and growth retardants on bud development and cold hardiness of peach. Proc. Amer. Soc. Hort. Sci. 88:197-203.

Garcia-Pallas, I., J. Val, and A. Blanco. 2001. The inhibition of flower bud differentiation in 'Crimson Gold' nectarine with $\mathrm{GA}_{3}$ as an alternative to hand thinning. Sci. Hort. (Amsterdam) 90:265-278.

Greene, D.W. 2004. Blossom thinning as a strategy in chemical thinning of apples in New England. Acta Hort. 636:331-337.

Ho, L.C. 1988. Metabolism and compartmentation of imported sugars in sink organs in relation to sink strength. Annu. Rev. Plant Physiol. Plant Mol. Biol. 39:355-378.

Hull, J., Jr. and L.N. Lewis. 1959. Response of oneyear-old cherry and mature bearing cherry, peach and apple trees to gibberellin. Amer. Soc. Hort. Sci. 74:93-100.

McGuire, R. 1992. Reporting of objective color measurements. HortScience 27:1254-1255.

Monge, E., R. Aguirre, and A. Blanco. 1994. Application of paclobutrazol and $\mathrm{GA}_{3}$ to adult peach trees: effects on nutritional status and photosynthetic pigments. J. Plant Growth Regulat. 13:15-19.

Painter, J.W. and G.E. Stembridge. 1972. Peach flowering response as related to time of gibberellin application. HortScience 7:389-390.
Slingerland, K. and In: J. Molenhuis (Ed.). 2003. Establishment and production costs for tender fruit in Ontario: 2002 economic report. Publication 817. Ontario Ministry of Agriculture and Food. K. Slingerland and Queen's Printer for Ontario, Toronto.

Southwick, S.M. and R. Fritts, Jr. 1995. Commercial chemical thinning of stone fruit in California by gibberellins to reduce flowering. Acta Hort. 394:135-147.

Southwick, S.M. and K. Glozer. 2000. Reducing flowering with gibberellins to increase fruit size in stone fruit trees: applications and implications in fruit production. HortTechnology 10:744-751.

Southwick, S.M., K.G. Weis, and J.T. Yeager 1996. Bloom thinning 'Loadel' cling peach with a surfactant. J. Amer. Soc. Hort. Sci. 121:334-338.

Southwick, S.M., K.G. Weis, J.T. Yeager, and H. Zhou. 1995. Controlling cropping in 'Loadel' cling peach using gibberellin: effects on flower density, fruit distribution, fruit firmness, fruit thinning, and yield. J. Amer. Soc. Hort. Sci. 120:1087-1095.

Southwick, S.M., J.T. Yeager, and K.G. Weis. 1997. Use of gibberellins on 'Patterson' apricot (Prunus armeniaca) to reduce hand thinning and improve fruit size and firmness: effects over three seasons. J. Hort. Sci. 72:645-652.

Taylor, B.H. and D. Geisler-Taylor. 1998. Flower bud thinning and winter survival of 'Redhaven' and 'Cresthaven' peach in response to $\mathrm{GA}_{3}$ sprays. J. Amer. Soc. Hort. Sci. 123:500-508.

The OMRI Products List-a Directory of OMRI Listed Products. [5 Apr. 2006] http://www. omri.org/OMRIproducts list.html.

Ward, D.L. 1993. Reducing flower bud density of 'Redkist' peach with $\mathrm{GA}_{3}$. MA thesis. Southern Illinois Univ., Carbondale, Ill.

Weinberger, J.H. 1941. Studies on time of peach thinning from blossoming to maturity. Proc. Amer. Soc. Hort. Sci. 38:137-140. 